Reprod. Nutr. Dévelop., 1980, 20 (3 A), 653-663.

\title{
Electron microscopic study of follicle cell development during vitellogenesis in the marine crustacean Isopoda, Idotea balthica basteri
}

par Catherine SOUTY

\author{
Laboratoire de Biologie animale \\ Physiologie et Génétique des Crustacés, ERA CNRS 230 \\ 40, avenue du Recteur Pineau, 86022 Poitiers Cedex, France.
}

Summary. The ultrastructure of follicle cells has been compared to that of developing oocytes in the marine crustacean isopod, Idotea balthica basteri, at different periods of the molting cycle. There was a distinct change in the shape and size of the follicles and in their relation to each other and to the oocytes. During stage 1 of vitellogenesis (molting cycle period $\mathrm{C}$ ), spaces between the follicles appeared and enlarged. At the same time, the exogenous yolk fraction penetrated the oocytes, and villi, issuing from both the follicle cells and the oocytes, formed. Maximal follicle cell activity occurred during stage 2 of vitellogenesis (molting cycle period D) when micropinocytotic uptake stopped. This cellular activity was characterized by the synthesis of some granular material and the development of the rough endoplasmic reticulum and the Golgi vesicle. The granular material participated in the formation of the chorion. The follicle celis seemed to degenerate shortly before laying, and thus the follicular epithelium did not appear to be permanent in Idotea.

\section{Introduction.}

The cytochemistry, and particularly the origin, of oocyte yolk inclusions have been thoroughly studied in several crustaceans using electron microscopy : the endogenous origin of the yolk protein in Orconectes (Beams and Kessel, 1963) and its endogenous and exogenous origin in Libinia emarginata (Hinsch and Cone, 1969), Orchestia gammarellus (Zerbib, 1973, 1976) and Eriocheir sinensis (Dhainaut and De Leersnyder, 1976). Only one ultrastructural study by Rateau and Zerbib (1978) concerns the follicle cells, but their possible secretory cycle and various functions have never been analyzed. Although lacking in crustaceans, many studies of this type have been carried out in insects : Anderson and Telfer (1970), Telfer and Bast (1971), Cruickshank (1971), Favard-Sereno (1971) and Nardon (1978). These authors generally agree that the insect endochorion and exochorion are produced by the follicle cells. Favard-Sereno (1971) observed that these envelopes were synthesized in the follicle cells during three successive secretory cycles. The size of the Golgi compartment increases considerably, as Beams and Kessel (1969) in the dragonfly and Quattropani and Anderson (1969) in Drosophila have shown. 
While it is not known if the yolk protein in crustaceans is synthesized by the hepatopancreas or hemocytes and transported by the hemolymph, there is a large body of knowledge on this subject in insects. The yolk precursors are formed by the fat body, released in the hemolymph (Telfer, 1965), and then incorporated into the oocytes by micropinocytosis (Roth and Porter, 1964, in Aedes aegypti). But Cruickshank (1971), Telfer and Anderson (1969) and Telfer ahd Bast (1971) reported that the follicle cells in the Cecropia moth can synthesize the endogenous proteins incorporated into the yolk after binding to the hemolymph proteins (Melius and Telfer, 1969).

Idotea balthica basteri is useful experimental material for it reproduces continuously from puberty to death and has a short ovarian cycle of 18 days in the laboratory $\left(20^{\circ} \mathrm{C} ; 18 \mathrm{~L}-6 \mathrm{D}\right.$ photoperiod). Moreover, the ovarian and the molting cycles are closely correlated, and the latter cycle may be subdivided into periods and stages by studying the teguments (general method: Drach and Tchernigovtzeff, 1967). A preliminary histological study (Biometry, Souty, 1978), using Besse's terminology (1976) in the terrestrial isopod, Porcellio dilatatus, distinguished three stages of vitellogenesis sensu lato and correlated them with molting cycle periods.

TABLE 1

\begin{tabular}{|c|c|c|c|c|c|c|c|c|c|}
\hline \multirow[t]{2}{*}{ Ovarian cycle } & \multicolumn{2}{|c|}{ Previtellogenesis } & \multicolumn{3}{|c|}{$\begin{array}{l}\text { Stage } 1 \text { of } \\
\text { vitellogenesis }\end{array}$} & \multicolumn{3}{|c|}{$\begin{array}{l}\text { Stage } 2 \text { of } \\
\text { vitellogenesis }\end{array}$} & Laying \\
\hline & \multicolumn{9}{|c|}{ Oocytes } \\
\hline \multirow{3}{*}{$\begin{array}{l}\text { Molting } \\
\text { cycle } \\
\text { period }\end{array}$} & Period A & Period B & \multicolumn{3}{|c|}{ Period C } & \multicolumn{3}{|c|}{ Period D } & Molt \\
\hline & & & \multicolumn{3}{|c|}{ Stages } & \multicolumn{3}{|c|}{ Stages } & \\
\hline & & & $c_{1}$ & $\mathrm{C}_{2}$ & $\mathrm{C}_{3}$ & $\mathrm{D}_{0}$ & $D_{1}$ & $\mathrm{D}_{2}$ & E \\
\hline Diameter $(\mu \mathrm{m}) \ldots \ldots$ & 50 & $80-90$ & $90-100$ & $\mid 100-140$ & $140-180$ & $180-200$ & $200-400$ & \multicolumn{2}{|c|}{$400-500$} \\
\hline Cycle (Days) ........ & 1 & 1 & & $7-8$ & & & 7 & & 2 \\
\hline
\end{tabular}

The present ultrastructural study reconsiders the definitions of previtellogenesis and stages 1 and 2 of vitellogenesis, and demonstrates that the pubescent female ovary contains two oocyte populations:

- a first population, laid during the next molt and including oocytes with a diameter increasing from 90 to $500 \mu \mathrm{m}$ during the following intermolt, and

- a second population of younger oocytes, issuing from the germinal band oogonia and maintained in a stationary state after early premeiosis and nuclear reversion to a vegetative phase. This population began vitellogenesis after the first population was laid.

Since little is known about follicle cell origin, this study attempts to describe the development of the first oocyte population and the follicle cells as well as the oocytefollicle cell relationship. According to Besse (1976), the follicular tissue in Porcellio dilatatus derives from a germinal prefollicular epithelium, while Charniaux-Cotton (1974) studying Orchestia gammarellus believes that tissue is permanent. 


\section{Material and methods.}

The crustacean isopod, Idotea balthica basteri, used in this study and born and reared in our laboratory, originated from a population in Marseille. The ovaries were dissected at different periods of the molting cycle, and fixed for $1 \mathrm{~h}$ at $4{ }^{\circ} \mathrm{C}$ in 8 p. 100 glutaraldehyde and 7 p. $100 \mathrm{NaCl}$ in a $0.4 \mathrm{M}$ cacodylate buffer at $\mathrm{pH} 7.4$. The ovarian samples were washed in sucrose then postfixed at $\mathrm{pH} 7.4$ in $4 \mathrm{p} .100 \mathrm{OsO}_{4}$ in the same buffer with a trace of $\mathrm{CaCl}_{2}$ for membrane protection (Gobel and Witkus, 1966). Osmolarity was 1150 mOsm. After dehydration with a graded alcohol series and long impregnation, they were embedded in Spurr's low viscosity medium (Spurr, 1969). Even after the long Araldite impregnation, the oocyte sections in stage 2 of vitellogenesis were poor; the same result was obtained with previtellogenetic oocytes embedded in Araldite or Spurr. We used Spurr since it is suitable for heterogeneous tissues and could be used with marine material and developing oocytes (Zerbib, 1975, in Orchestia gammarellus and Peaucellier, 1977 in Sabellaria alveolata) ; it is difficult to find an embedding medium suited to both uses. The sections were stained for $15 \mathrm{~min}$ with uranyl acetate, doublestained for $4 \mathrm{~min}$ with lead citrate according to Reynolds (1963), and then observed with an Hitachi HU 11 CS electron microscope and a JEOL $100 \mathrm{C}$ electron microscope.

\section{Results.}

- Previtellogenesis (molting cycle periods $A$ and $B$ ).

Oocytes. - The oocytes were 60 to $80 \mu \mathrm{m}$ in diameter and had a perfectly smooth surface (fig. 2). The nucleus contained an heterogeneous nucleolus with a granular part and many laminae. Numerous ribosomes and nuclear extrusion from the nuclear pores (fig. 1) were visible. When the oocytes reached 80 to $90 \mu \mathrm{m}$ in diameter at the end of period $B$, small rough endoplasmic reticulum (ER) cisternae, containing endogenous yolk granules, developed (fig. 3). Their appearance on the oocyte denoted the onset of true vitellogenesis and, at that moment, short microvilli appeared.

Follicle cells. - The oocytes were surrounded by a continuous layer of follicle cells with an ovoid nucleus (5-6 $\mu \mathrm{m}$ by $2-3 \mu \mathrm{m}$ ) whose chromatin (fig. 2) was distributed in numerous aggregates lying close to the nuclear envelope. As early as the end of previtellogenesis (fig. 5), intercellular spaces about $5 \mathrm{~nm}$ wide appeared between the cells which were initially apposed by several desmosomes (fig. 4). The cell cytoplasm contained a rough ER, short mitochondria (fig. 2) and numerous Golgi vesicles (fig. 6).

\section{- Stage 1 of vifellogenesis (molting cycle period C).}

Oocytes. - The oocytes were $100 \mu \mathrm{m}$ in diameter and well-formed microvilli were visible, coinciding with micropinocytotic penetration of the exogenous yolk (fig. 7). An homogeneous substance, observed between the microvilli, became more dense as it penetrated into the oocyte to form granules coalescing into larger yolk granules (fig. 8). Endogenous yolk synthesis continued actively in the ergastoplasmic cisternae. 
PI. I.
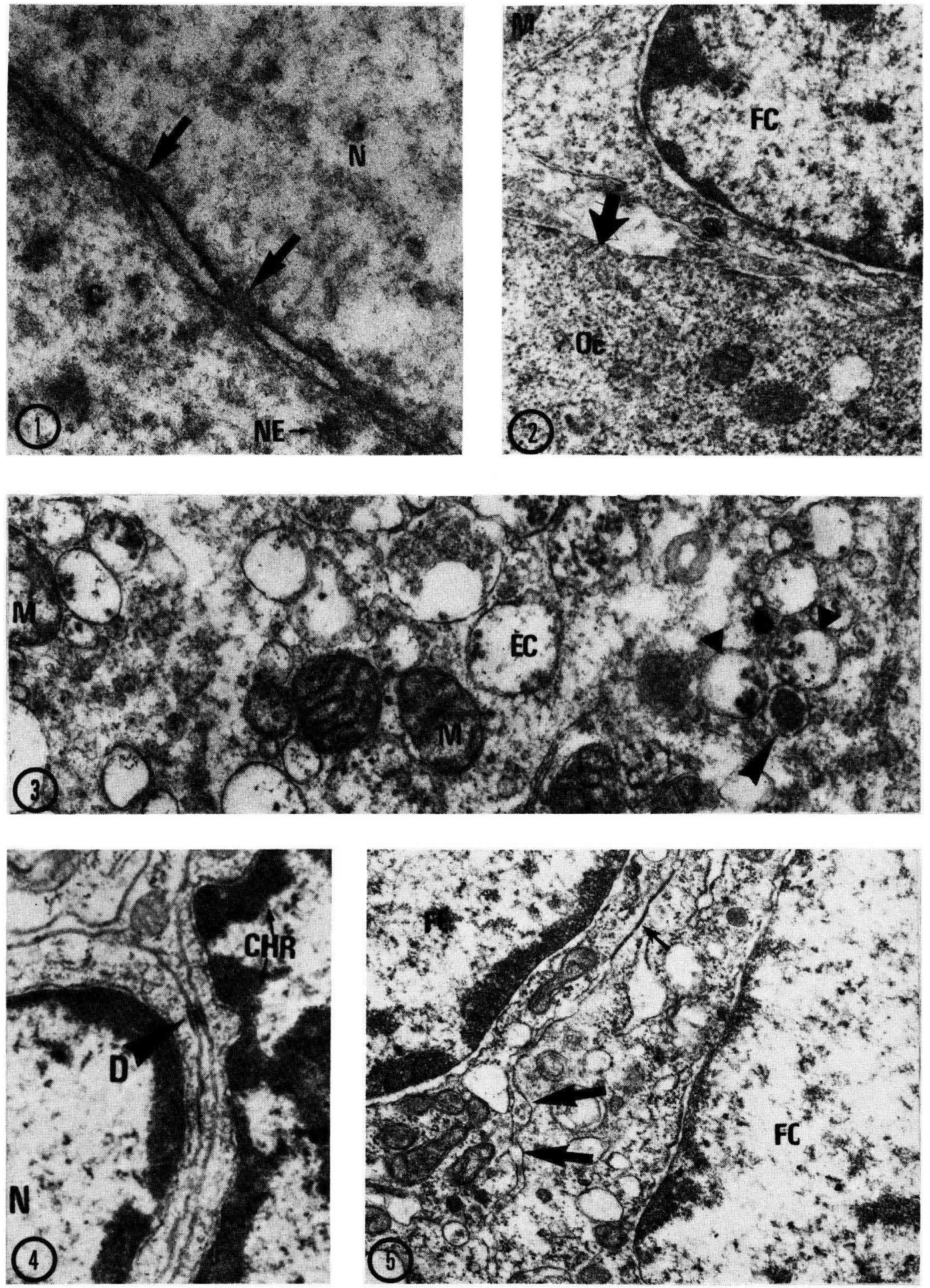
Follicle cells. - During this period, the follicle cells also acquired oocyte-oriented villi (fig. 9, 10). The cell junctions between the oocyte microvilli and the follicle cell villi (fig. 11) sometimes resembled desmosomes (white arrow) but more often septate junctions (black arrow). Follicle cell cytoplasm at the onset of this stage (molting cycle stage $C_{1}$ ) contained short mitochondria which began to lengthen during stage $C_{3}$. The rough ER became more abundant, and free ribosomes and active Golgi vesicles were numerous as in previtellogenesis. The intercellular spaces were very wide (about $10 \mathrm{~nm}$ ) and no desmosomes were visible (fig. 12).

- Stage 2 of vitellogenesis (molting cycle period D).

Oocyfes. - Oocyte volume increased considerably (200 to $500 \mu \mathrm{m}$ ) and mature yolk inclusions gradually appeared. Micropinocytotic uptake, still occurring sometimes during stage $D_{0}$, stopped completely at the onset of stage $D_{1}$. Electron-dense material, representing an envelope, was rapidly deposited between the microvilli (fig. 13 ; stage $\left.D_{0}\right)$.

Follicle cells. - While oocyte volume increased as seen above, the follicle cells lengthened, the tight junctions between follicular villi and oocyte microvilli being maintained. Junctions between the oocyte microvilli and the follicle cell plasma membrane were even apparent (fig. 14). The follicle cells flattened progressively, and their nucleus elongated from 5 to $8.5 \mu \mathrm{m}$, while their width augmented from 1.1 to $1.8 \mu \mathrm{m}$. The cytoplasm showed considerable secretory activity as seen by the abundance of long mitochondria and the development of the rough ER (fig. 15) in relation to the Golgi vesicles. This follicle cell synthesis increased during stages $D_{1}$ and $D_{2}$. Granules of material were released into the intercellular spaces to form an envelope having a dented aspect on the follicle cell side and being linear on the oocyle side (fig. 16).

\section{PLATE I}

FIG. 1. - Previtellogenesis. Arrows show nuclear extrusions through nuclear pores. $\Varangle 71000$.

FIG. 2. - Previtellogenesis. Oocyte surface is smooth (arrow). $\times 24000$.

FIG. 3. - End of previtellogenesis. Oocyle cyfoplasm : note development of small ergastoplasmic cisternae containing endogenous yolk granules (arrow), mifochondria. $\times 30000$.

FIG. 4. - Previtellogenesis. Follicular tissue : note desmosomes, nucleus with dense chromatin aggregation lying close to the nuclear envelope. $\times 30000$.

FIG. 5. - End of previtellogenesis. Follicle cells : note appearance of intercellular spaces while a junction gap remains. $\times 21000$.

FIGS. 1-17. - Abbreviations used : cytoplasm (C), chromatin (CHR), desmosome (D), ergastoplasmic cisternae (EC), follicle cells (FC), Golgi vesicle (GV), mitochondria (M), microvilli (MV), nucleus $(N)$, nuclear extrusions $(\mathrm{NE})$, nucleolus $(\mathrm{Na})$, oocyte $(\mathrm{Oc})$, villi $(v)$. 
PI. II.
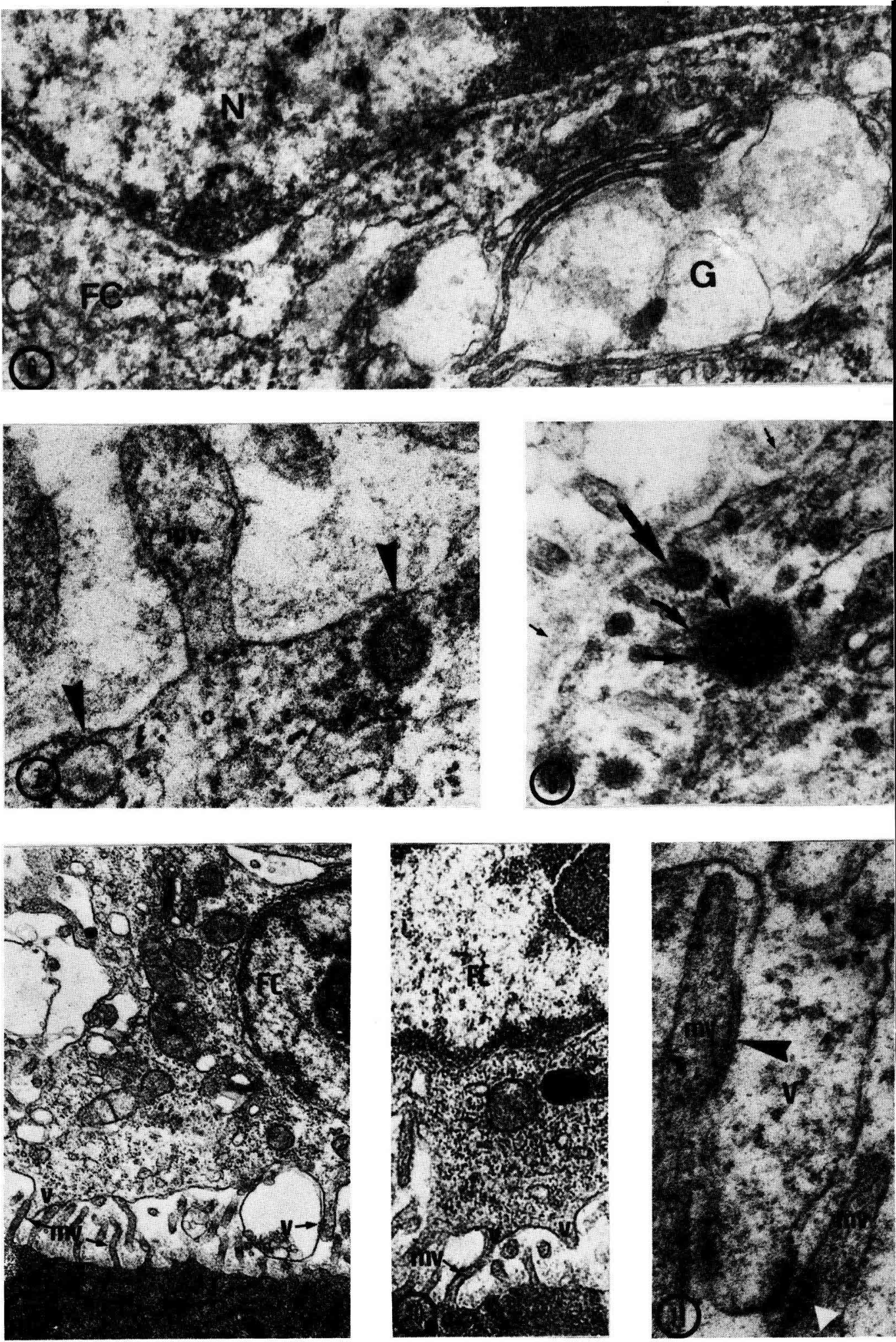
- End of vifellogenesis.

Oocyfes. - At the end of stage $D_{2}$, the oocytes attained a maximum diameter of $500 \mu \mathrm{m}$ since molting was imminent and the female would copulate. Their microvilli disappeared, and the envelope, which was partitioned before by the microvilli, then presented an uninterrupted aspect and continued to develop owing to the deposition of material.

Follicle cells. - These cells seemed to degenerate; their cytoplasm was lacunar, the mitochondria were abnormal and the nucleus seemed to be pyknotic (fig. 17).

\section{Discussion.}

This study shows a progression of follicle cell structure and activity concomitant with oocyte development in Idotea balthica basteri. During molting cycle period B, intercellular spaces appeared between the follicle cells which were closely apposed by several desmosomes during period A ; during period $C$, these spaces enlarged while the desmosomes disappeared. As Rateau and Zerbib (1978) have reported, it may be that the spaces, as reported in insects by Nardon (1978), provide a route for transfollicular penetration of the exogenous yolk fraction. The female specific protein fraction has been shown experimentally by Besse and Mocquard (1968) and Picaud and Besse (1973), Besse (1976) in Porcellio dilatatus, and we also reported it using disc electrophoresis in Idotea balthica (Souty, 1978).

The follicle cell villi also elongate towards the oocytes during period $C$, even contacting the oocyte microvilli which appear in the same period. These follicular villi are well known in molluscs (Dhainaut and Richard, 1976), insects (Telfer and Bast, 1971) and all vertebrates, but have never been described in crustaceans. It should be noted that the villi appear when the exogenous yolk penetrates the oocytes by micropinocytosis. At the oocyte periphery, we observed a granular material, which seemed to be more dense in the micropinocytotic vesicles; similar observations were reported by Favard-Sereno (1964) in Gryllus bimaculatus. This material does not

\section{PLATE II}

FIG. 6. - Previfellogenesis. Follicle cell : note Golgi vesicle activity (G). $\ 57000$.

FIG. 7. - Stage 1 of vitellogenesis (stage $C_{1}$ ). Oocyte : pinocytotic vesicles appear (arrows). Y. 90000.

FIG. 8. - Stage 1 of vitellogenesis (stage $C_{1}$ ). Arrows indicate pinocytotic vesicles coalescing into yolk granules in the oocytes. $\times 54000$.

FIGS. 9 and 10. - Stage 1 of vifellogenesis (period C). Follicle cell cytoplasm contains numerous mitochondria $(M)$, free ribosomes and a rough ER. Oocyte-oriented microvilli (arrows) appear. × 18000 .

FIG. 11. - Stage 1 of vitellogenesis. Relations between follicle cell villi and oocyte microvilli. White arrow indicates a desmosome, black arrow shows a septate junction. $\succ 87000$. 

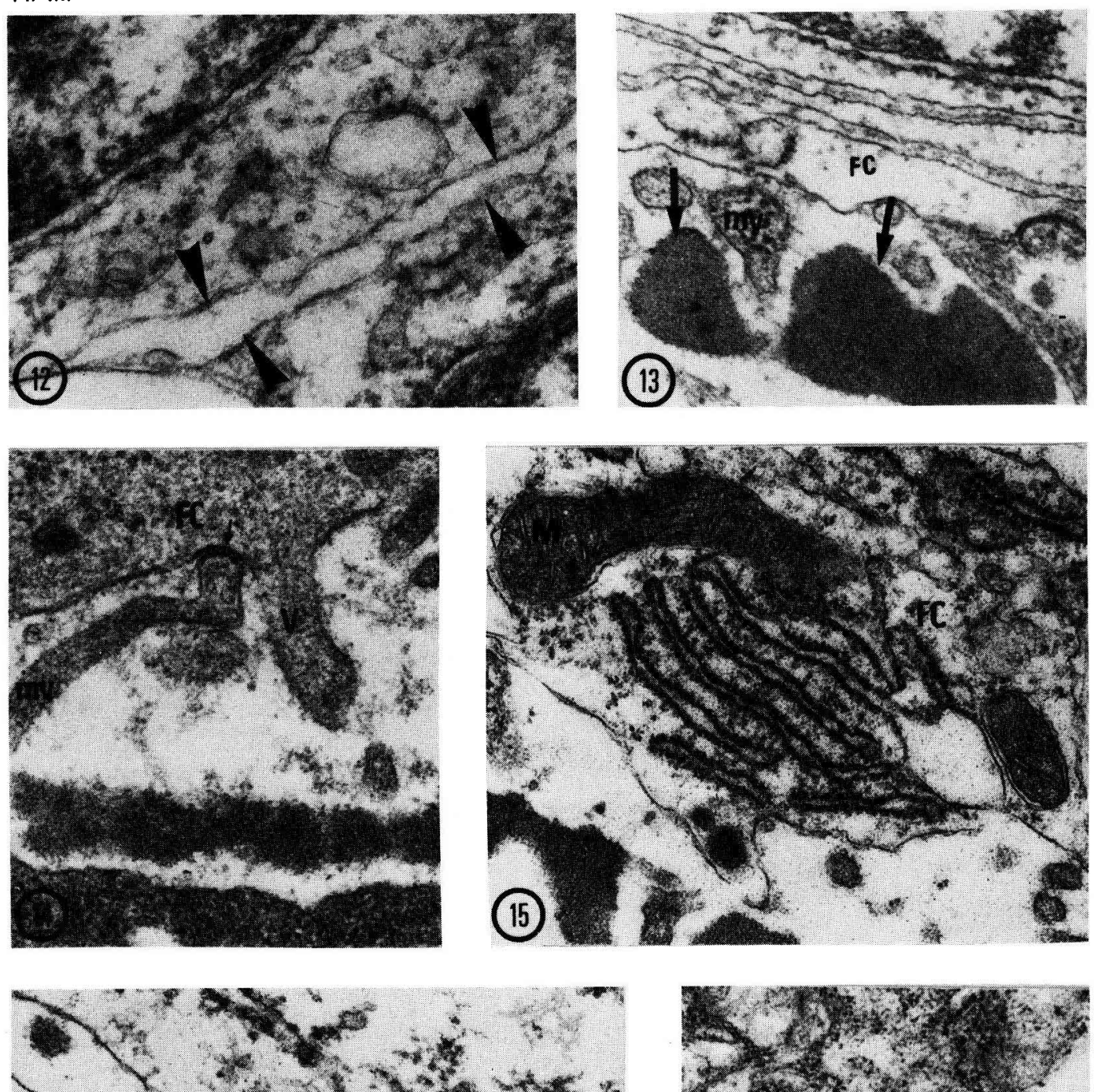

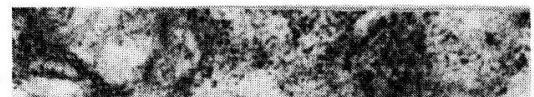

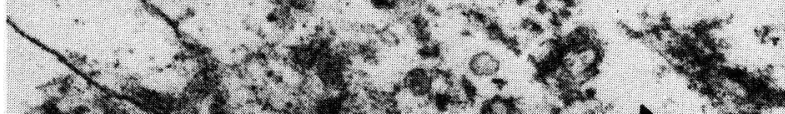
2.1 5,284 $2302 x+5$

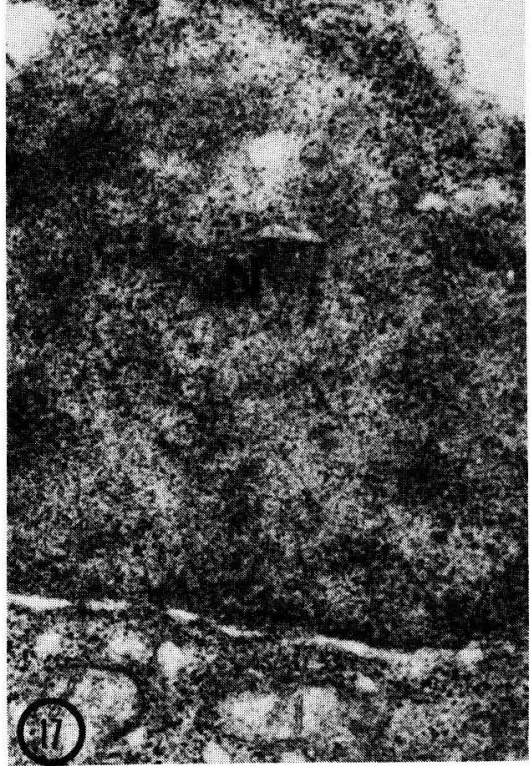

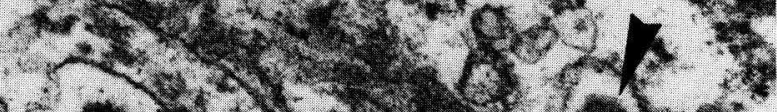

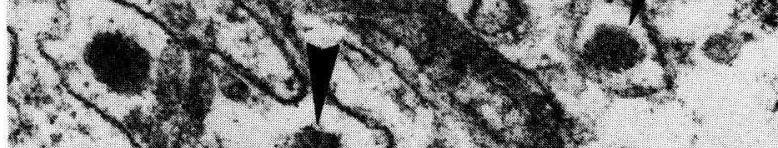

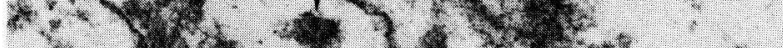

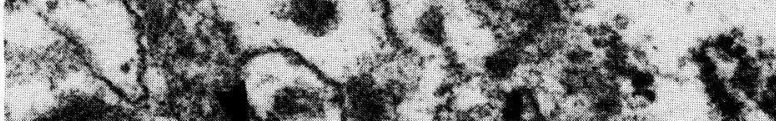

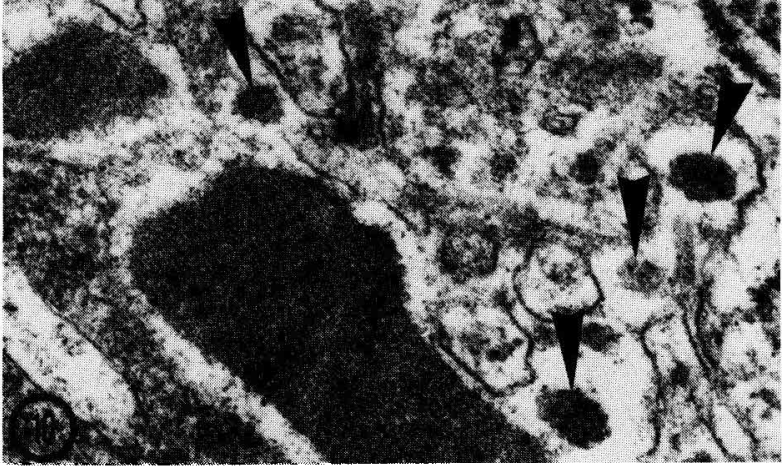


seem to represent the beginning of an envelope resulting from follicle cell secretion since those cells do not produce any granules during this phase. On the other hand, the coalescing granules at the oocyte periphery, resulting from the penetration of dense vesicles, suggests that, contrary to Zerbib's hypothesis (1978), oocyte material exocytosis is not at the origin of the yolk envelope. However, the suggestion that hemolymph yolk protein is responsible must be demonstrated cytochemically. This protein might be agglutinated by a follicle cell factor, as indicated by Anderson and Telfer $(1970 a, b)$ in Hyalophora cecropia.

During period $D$, which coincides with the end of pinocytosis, the activity of the follicle cell organelles - abundant rough ER and Golgi vesicles - intensified, as demonstrated by electron-dense granule formation. These granules were deposited between the microvilli in the spaces between the oocytes and follicle cells, forming an envelope comparable to the chorion in insects. During stage D2, a few multilamellar bodies were seen in the follicle cells.

The follicle cells seemed to be degenerating a few hours before laying ; the nucleus seemed to be pyknotic and the electron-dense cytoplasm released a few granules which were incorporated into the chorion.

\section{Conclusion.}

Our observations support the hypothesis that the follicular tissue plays at least a passive role in exogenous yolk penetration by opening the intercellular spaces providing a route for these substances, and contributes substantially to the formation of an envelope homologous to the chorion in insects. The function which has been assigned to the follicle cells by Rateau and Zerbib (1978) - that of producing the female hormone - was not confirmed by the organelle activity in our study, unless such activity occurred without the appearance of secretory granules during

\section{PLATE III}

FIG. 12. - Stage 1 of vifellogenesis. Wide intercellular spaces; no desmosomes present. $\times 60000$.

FIG. 13. - Stage 2 of vitellogenesis. Junction between oocyte microvilli and follicle cell plasma membrane. $\times 66000$.

FIG. 14. - Stage 2 of vitellogenesis. Junction between oocyte microvilli and follicle cell plasma membrane. $\times 66000$.

FIG. 15. - Stage 2 of vifellogenesis (stage DO). Follicle cells : note abundant development of rough ER, elongated mitochondria. $\times 32500$.

FIG. 16. - Stage 2 of vitellogenesis (stage D2). Follicle cells : synthesis of material deposited in the intercellular spaces and forming the chorion (arrows). $\times 36000$.

FIG. 17. - End of vifellogenesis (just prior to molting). The chorion is continuous, the follicle cells seem to be degenerating, and the nucleus appears pyknotic. $\times 57000$. 
molting cycle period $C$ when the rough $E R$ and Golgi vesicles were active. Other studies have demonstrated that, as concerns the terminal oocytes, the follicle cells play a role in egg resorption (Souty, 1978). This follicular tissue cannot apparently be considered as permanent because the follicle cells seem to degenerate just prior to laying.

Our study of oocytes also obliges a change in the definitions of the stages of vitellogenesis sensu lato. In fact, molting cycle period B coincides with the onset of endogenous yolk synthesis, which continues later whan the exogenous yolk is incorporated into the oocyfes. It would be logical, therefore, to combine periods $B$ and $C$ in stage 1 of vitellogenesis. Thus, period A which follows molting, would be the end of previtellogenesis, a period which begins during the previous intermolting cycle. At that time, the young oocytes, whose development has been relarded, begin to grow slowly, acquiring the organelles which play a future role in endogenous yolk synthesis and undoubtedly in the formation of mature yolk inclusions.

Reçu en juillet 1979.

Accepté en octobre 1979.

Résumé. L'étude ultrastructurale des cellules folliculaires aux différentes étapes du cycle de mue, rapportée à celle des ovocytes en vitellogenèse, chez Idotea balthica basteri, permet d'observer une nette évolution de leur forme, de leurs dimensions, de leurs organites, de leurs rapports entre elles ef avec l'ovocyte. L'apparition ef surtout l'élargissement des espaces séparant les cellules folliculaires au cours de la première phase de vitellogenèse (étape $C$ du cycle de mue) sont concomitants de la pénétration - dans l'ovocyte - de la fraction exogène du vitellus ainsi que de la formation de villosités émanant à la fois des cellules folliculaires et des ovocytes. L'activité maximale des cellules folliculaires, marquée par la synthèse (par l'ergastoplasme ef le Golgi) d'un matériel granulaire à l'origine du chorion, intervient au cours de la deuxième phase de vitellogenèse (période $D$ du cycle de mue), lorsque cesse la pinocytose. Les cellules folliculaires semblent dégénérer peu avant la ponte ; le tissu folliculaire ne serait donc pas permanent chez ce Crustacé Isopode.

\section{References}

ANDERSON L. M., TELFER W. H., 1970a. Extracellular concentration of proteins in the Cecropia moth follicle. J. Cell Physiol., 76, 37-53.

ANDERSON L. M., TELFER W. H., 1970b. Trypan blue inhibition of yolk deposition : a clue to follicle cell function in the Cecropia moth. J. Embryol. exp. Morphol., 23, 35-52.

BEAMS H. W., KESSEL R. G., 1963. Electron microscope studies on developing, crayfish oocytes. with special reference to the origin of the yolk. J. Cell. Biol., 18, 621-650.

BEAMS H. W., KESSEL R. G., 1969. Synthesis and deposition of oocyte envelopes (vitelline membrane, chorion) and the uptake of yolk in the dragonfly (Odonata: Aeschnidae). J. Cell. Sci., 4, 241-264.

BESSE G., MOCQUARD J. P., 1968. Etude par électrophorèse des quantités relatives des protéines de l'hémolymphe d'individus normaux et de femelles castrées chez deux Crustacés Oniscoïdes : Porcellio dilatatus Brandt et Ligia oceanica L. C. R. Acad. Sci: Paris, 267, 2017-2019.

BESSE G., 1976. Contribution à l'éfude expérimentale de la physiologie sexuelle femelle chez les Crustacés Isopodes Terrestres. Th. Doct. d'Etat, CNRS, n AO 13017.

CHARNIAUX-COTTON H., 1974. Données nouvelles concernant la vitellogenèse des Crustacés Malacostracés obtenues chez l'Amphipode Orchestia gammarellus (Pallas); folliculogenèse à partir d'un tissu permanent; action du Busulfan ; action inhibitrice de l'hormone juvénile. C. R. Acad. Sci. Paris, sér. D. 279, 563-566.

CRUICKSHANK W. J., 1971. Follicle cell protein synthesis in moth oocytes. J. Insect Physiol., 17, 217-232. 
DHAINAUT A., RICHARD A., 1976. Vitellogenèse chez les Céphalopodes Décapodes. Evolution de l'ovocyte et des cellules folliculaires au cours de la małuration génitale. Arch. Anot. micr. Morph. exp., 65, 182-208.

DHAINAUT A., DE LEERSNYDER M., 1976a. Etude cytochimique et ultrastructurale de l'évolution ovocytaire du crabe Eriocheir sinensis. I. Ovogenèse nafurelle. Arch. Biol. (Bruxelles), 87, $261-282$.

DHAINAUT A., DE LEERSNYDER M., 1976b. Etude cytochimique et ultrastructurale de l'évolution ovocytaire du crabe Eriocheir sinensis. II. Ovogenèse après ablation des pédoncules oculaires. Arch. Biol. (Bruxelles), 87, 283-302.

DRACH P., TCHERNIGOVTZEFF C., 1967. Sur la méthode de détermination des stades d'intermue et son application générale aux Crustacés. Vie et Milieu, Sér. A., Biol. mar., 18, 595-610.

FAVARD-SERENO C., 1964. Phénomènes de pinocytose au cours de la vitellogenèse protéique chez le grillon (Orthoptère). J. Microscopie, 3, 323-338.

FAVARD-SERENO C., 1971. Cycles sécrétoires successifs au cours de l'élaboration des enveloppes de l'ovocyte chez le Grillon (Insecte Orthoptère). J. Microscopie, 11, 401-424.

GOBEL S., WITKUS E. R., 1966. Electron microscopical studies on the plasma membranes of cerebellar neurons and astrocytes. J. Ultrastruct. Res., 15, 310-325.

HINSCH G. W., CONE M. V., 1969. Ultrastructural observations of vitellogenesis in the spider crab Libinia emarginata L. J. Cell Biol., 40, 336-342.

MELIUS M. E., TELFER W. H., 1969. An autoradiographic analysis of yolk deposition in the cortex of the Cecropia moth oocyte. J. Morph., 129, 1-16.

NARDON P., 1978. La synthèse ef l'accumulation d'acides nucléiques ef de protéines au cours de l'ovogenèse chez les Insectes. Ann. Biol., 17, 105-146.

PEAUCELLIER G., 1977. Initiation of meiotic maturation by specific proteases in oocytes of the polychaete. Annelid Sabellaria alveolata. Exper. Cell Res., 106, 1-14.

PICAUD J. L., BESSE G., 1973. Les protéines de l'hémolymphe et de l'ovaire de Porcellio dilatatus Brdf : leurs variations en fonction de la vitellogenèse C. R. Acad. Sci. Paris, sér. D, 276, 2207-2210.

QUATTROPANI S. L., ANDERSON E., 1969. The origin and structure of the secondary coat of the egg of Drosophila melanogaster. Z. Zellforsch., 95, 495-510.

RATEAU J. G., ZERBIB C., 1978. Etude ultrastructurale des follicules ovocytaires chez le Crustacé Amphipode Orchestia gammarellus (Pallas). C. R. Acad. Sci. Paris sér. D, 286, 65-68.

REYNOLDS E. S., 1963. The use of lead citrate at high $\mathrm{pH}$ as an electron opaque stain in electron microscopy. J. Cell Biol., 17, 208-212.

ROTH T. F., PORTER K. R., 1964. Yolk protein uptake in the oocyles of the mosquito Aedes aegypfi L. J. Cell Biol., 20, 313-332.

SOUTY C., 1978. Contribution à l'étude de l'ovogenèse d'ldotea balthica basteri (Audouin) : évolution cyfosfructurale des ovocytes; action des facteurs externes sur la corrélation mue-vitellogenèse. Th. $3^{\mathrm{e}}$ cycle, Univ. Poitiers.

SPURR A. R., 1969. A low viscocity epoxy resin embedding medium for electron microscopy. J. Ultrastruct. Res., 26, 31-43.

TELFER W. H., 1965. The mechanism and control of yolk formation. Arin. Rev. Entomol., 10, 161-184.

TELFER W. H., ANDERSON L. M., 1969. A follicle cell contribution to he yolk spheres of moth oocytes. Tissue Cell, 1, 633-644.

TELFER W. H., BAST E., 1971. Follicle cell protein synthesis and its contribution to the yolk of the Cecropia moth ovocyte. Develop. Biol., 52, 83-97.

ZERBIB C., 1973. Contribution à l'étude ultrastructurale de l'ovocyfe chez le Crustacé Amphipode Orchestia gammarella Pallas. C. R. Acad. Sci. Paris, sér. D, 277, 1209-1212.

ZERBIB C., 1975. Première observation de granules corticaux dans l'ovocyfe d'un Crustacé, l'Amphipode Orchestia gammarella (Pallas). C. R. Acad. Sc. Paris, sér. D, 281, 1345-1347.

ZERBIB C., 1976. Nature chimique des enclaves vitellines de l'ovocyte du Crustacé Amphipode Orchestia gammarellus (Pallas). Ann. Histochim., 21, 279-295.

ZERBIB C., 1978. Ovogenèse chez le Crustacé Amphipode Orchestia gammarellus (Pallas) : contribution à son éfude cytologique et physiologique. Th. Doct. d'Etat, Univ. P. ef M. Curie, Paris. 